\title{
A NOVA CIÊNCIA AMBIENTAL
}

F.Levi ${ }^{1}$

\section{A EMERGÊNCIA DE UMA NOVA CIÊNCIA}

$\mathrm{Na}$ metade do século passado, quando a população humana era aproximadamente $1 / 5$ da atual, as leis da ciência que regem as transformaçōes começaram a ser entendidas, num contexto que ainda separava os seres vivos e os sistemas inorgânicos, pelos resquícios de uma noção de força vital. Pouco se entendia do papel dos seres humanos na Terra.

Cem anos depois, nossa compreensão se aprimorou e começamos a procurar explicações mais unificadas. A população mundial, em 1950, havia aumentado por um fator de 2,5; e problemas ambientais de diversos tipos emergiam de forma crescente, indicando a capacidade limitada de tamponar dos sistemas naturais. Sabemos agora que há uma crise ambiental crescente que veio para ficar, mesmo apesar de especialistas e políticos tentarem ignorar, freqüentemente, o significado mais amplo dos danos ambientais locais, simplesmente considerando-os "desequilíbrios" de diversos tipos.

Raciocínio similar leva a considerar uma dificuldade crescente na classificação de recursos em renováveis ou não renováveis. Ao que tudo indica, no futuro, um novo recurso irá requerer, desde o início, estudos de reciclagem. Talvez por motivos semelhantes os problemas globais são cada vez mais e mais difíceis de serem ignorados.

\section{CIÊNCIA AMBIENTAL E GEOQUÍMICA}

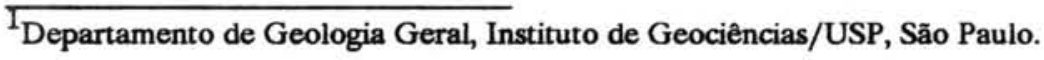


No decorrer do tempo, começamos a nos visualizar como partes de um ambiente que consiste de turbulências composicionais pertencentes a uma rede de alças conectadas denominada ciclo geoquímico. Se formos menos determinísticos, poderemos, de modo semelhante, afirmar que pertencemos a Gaia, um superorganismo. Entretanto, de todas as maneiras, nosso destino e aquele de nossos arredores é de sermos reciclados. Para entender a estrutura de alças do ciclo, as que nos envolvem e aquelas das quais fazemos parte, devemos começar a considerar as matérias-primas, os reagentes e produtos, tanto antes como depois que eles entram em nossos sistemas, laboratórios, indústrias e paisagens.

Como já não podemos exercer nossa autonomia como antigamente, já que os vínculos externos agora se mostram importantes, teremos de complementar a ciência clássica analítica ocidental "recolocando as partes de volta no todo", com um toque sintético de filosofia oriental.

$\mathrm{Na}$ virada do milênio sentimos que os problemas com grande número de variáveis não podem mais ser ignorados, ou rotulados de intratáveis, e que a complexidade deve ser encarada como tal. Ao invés de equilíbrios, devemos considerar seqüências de estados estacionários ou quase estacionários que se sucedem. Estruturas dissipativas, estabilizadas no decorrer de períodos variados, fundem a história com a física em termos de uma flecha unidirecional do tempo. Estes aspectos se tornam ainda mais complexos quando nos propomos considerar ciência e cultura de uma só vez, com palavras e conceitos como os átomos e moléculas de um ciclo ainda mais holístico, que inclua as dimensōes humanas das mudanças globais. Talvez devamos tentar visualizar também a nós mesmos termodinamicamente, sustentados por fluxos externos de matéria e energia...

Ao inserir sistemas artificiais num contexto de sistemas naturais "previamente existentes" somos tentados a nos encarar como fatores de desequilíbrio, de alguma forma situados fora da natureza. A tarefa de lidar com alguns de nossos elos perdidos nos leva assim a exageradas simplificações no estudo da relação homem-natureza, vendo a nós mesmos como perturbações de um estado estacionário que teria prevalecido no passado. Na verdade nunca houve equilíbrio, de acordo com a nova maneira de ler os registros, havia sustentação graças à manutenção de distâncias do equilíbiro.

Considerações desse tipo permitem, durante um curto intervalo de tempo, que nos livremos das dicotomias desagradáveis entre sujeito e objeto e entre causa e efeito. A longo prazo, entretanto, é requerido um cenário onde o ser humano se destina a ser transformado em algum tipo de cidadão terrestre, integrado nos processos naturais e, de algum modo, se identificando como parte de uma seqüência histórica unificada. 
Agora, portanto, se faz necessário desfazer a torre de Babel das especializações, na busca das características centrais de uma ciência unificada do ambiente. Talvez já possamos identificar algumas dessas características, reconhecendo que:

- A compartimentalização, o reducionismo e a falta de perspectivas históricas são feições que caracterizam profissões e os campos do conhecimento tradicionais que estão desencaminhando nossa racionalidade em nome de antigas panacéias (as de quem sabe "mais que os outros").

- Às ciências "objetivas" devemos acrescentar uma "metaciência", o estudo dos respectivos contextos, das condições de seu surgimento, além das dimensões éticas, estéticas e políticas de cada faceta de nossa cultura.

Devemos estabelecer valores para bens e recursos ambientais que foram até aqui desprezados, no alcance de todas as escalas, considerando paisagens, espécies biológicas culturas, grupos minoritários, indivíduos, órgãos, mensagens genéticas, etc., como tendo valor por si só; mesmo que escolhas muito difíceis devam ser efetuadas durante os estágios posteriores de síntese, nos quais as prioridades terão de ser discutidas mais a fundo.

Encarar toda esta complexidade é uma necessidade que se impõe para enfrentar um paradoxo: ciência e técnica acumulam continuamente melhoras setoriais e um aprimoramento da qualidade de vida que só ocorre de modo muito limitado no espaço e no tempo, pois nas escalas maiores, e para a grande maioria dos habitantes da Terra, a qualidade de vida só tem piorado.

Enfrentar um paradoxo requer pois uma nova ciência, cuja emergência é dificultada por uma tradição de tipos de raciocínio imediatistas referidos à competência de profissões tradicionais nas quais, de um modo geral, a quantidade tenta, inutilmente, substituir a qualidade, mas acaba apontando um impasse: o excesso de coisas consideradas boas pode ser prejudicial. 